Article

\title{
Impact of Indo-Pacific Climate Variability on High Streamflow Events in Mahanadi River Basin, India
}

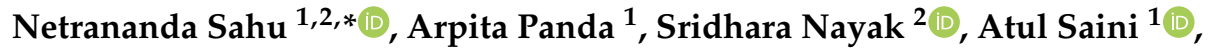 \\ Manoranjan Mishra ${ }^{3}{ }^{(D}$, Takahiro Sayama ${ }^{2}$, , Limonlisa Sahu ${ }^{4}$, Weili Duan ${ }^{5}$, , Ram Avtar 6 (D) \\ and Swadhin Behera ${ }^{7}$ D \\ 1 Department of Geography, Delhi School of Economics, University of Delhi, Delhi 110007, India; \\ arpitapanda1991@gmail.com (A.P.); atulsainimail@gmail.com (A.S.) \\ 2 Disaster Prevention Research Institute, Kyoto University, Kyoto 6110011, Japan; \\ nayak.sridhara.2n@kyoto-u.ac.jp (S.N.); sayama.takahiro.3u@kyoto-u.ac.jp (T.S.) \\ 3 Department of Natural Resource Management \& Geoinformatics, Khallikote University, Berhampur, Ganjam, \\ Odisha 760001, India; geo.manu05@googlemail.com \\ 4 Department of Environmental Science, Fakir Mohan University, Balasore, Odisha 756020, India; \\ sahulimona1995@gmail.com \\ 5 State Key Laboratory of Desert and Oasis Ecology, Xinjiang Institute of Ecology \& Geography, \\ Chinese Academy of Sciences, Urumqi 830010, China; duanweili@ms.xjb.ac.cn \\ 6 Faculty of Environmental Science, Hokkaido University, Sapporo 060-0810, Japan; ram@ees.hokudai.ac.jp \\ 7 Application Laboratory, JAMSTEC, Kanagawa 2360001, Japan; behera@jamstec.go.jp \\ * Correspondence: babunsahu@gmail.com
}

Received: 14 May 2020; Accepted: 2 July 2020; Published: 9 July 2020

\begin{abstract}
The potential impact of climate variability on the hydrological regime in the Mahanadi river basin is of great importance for sustainable water resources management. The impact of climate variability on streamflow is analyzed in this study. The impact of climate variability modes on extreme events of Mahanadi basin during June, July, and August (JJA), and September, October, and November ( $\mathrm{SON}$ ) seasons were analyzed, with daily streamflow data of four gauge stations for 34 years from 1980 to 2013 found to be associated with the sea surface temperature variations over Indo-Pacific oceans and Indian monsoon. Extreme events are identified based on their persistent flow for six days or more, where selection of the stations was based on the fact that there was no artificially regulated streamflow in any of the stations. Adequate scientific analysis was done to link the streamflow variability with the climate variability and very significant correlation was found with Indian Ocean Dipole (IOD), El Nino Southern Oscillation (ENSO), El Nino Modoki Index (EMI), and Indian monsoon. Agriculture covers major portion of the basin; hence, the streamflow is very much essential for agriculture as well as population depending on it. Any disturbances in the general flow of the river has subjected an adverse impact on the inhabitants' livelihood. While analyzing the correlation values, it was found that all stations displayed a significant positive correlation with Indian Monsoon. The respective correlation values were $0.53,0.38,0.44$, and 0.38 for Andhiyarkore, Baronda, Rajim, and Kesinga during JJA season. Again in the case of stepwise regression analysis, Monsoon Index for the June, July, and August (MI-JJA) season (0.537 for Andhiyarkore) plays significant role in determining streamflow of Mahanadi basin during the JJA season and Monsoon Index for July, August, and September (MI-JAS) season (0.410 for Baronda) has a strong effect in affecting streamflow of Mahanadi during the SON season. Flood frequency analysis with Weibull's plotting position method indicates future floods in the Mahanadi river basin in JJA season.
\end{abstract}

Keywords: streamflow; Mahanadi basin; climate variability; flood frequency analysis; correlation; regression 


\section{Introduction}

The frequency of hydrological extremes occurs more frequently with greater severity because of changes in climate extremes. The occurrence of floods is closely linked to climate change [1-3] and climate variability [4-6]. Sensitivity and flood frequency analysis of streamflow at seasonal and annual scale has been done in various river basins across the globe [7-12]. The floods exhibit regionally distinctive patterns of distribution, which are affected by both monsoon intensity and global climate change $[13,14]$. The potential impact of global climate change on the hydrological regime [15-17] of a region and the distribution of water resources in both upstream and downstream areas has been discussed widely in recent years [18]. Ward et al. [19] investigates the link between inter-annual climate variability and flood frequency and explained that the duration of flooding appears to be more sensitive to ENSO. Researchers from around the world have tended to concur that flood risk is the result of a combination of factors [20], but most importantly climate variability has a greater effect on the streamflow than human activities, including flood hazard as well as the exposure and vulnerability [21] of hazard bearing bodies. Thus, flood risk is closely related to the extreme precipitation that leads to run off [22,23]. To assess the impact of climate modes on freshwater resources, change in the mean annual run off is considered as first indicator [24]. The climatic factors override geology in controlling the inter-annual variability of streamflow $[25,26]$. The changes in risk of great floods, that is, floods with discharges exceeding 100-years from basins larger than 200,000 km² were analyzed by Christopher et al. [27], and it was found that the frequency of great floods increased substantially during the twentieth century, showing that there was a statistically significant positive trend in risk of great floods. Maghsood et al. [28], who assessed the impact of climate change on flood frequency and flood source area, revealed that the maximum temperature and annual precipitation could increase in near future, which is likely to lead an increase of instantaneous peak flow.

In wet tropical regions, study of climate warming effects on water resources is important due to the socioeconomic and ecological implications. Changes in the hydrological process that occurs due to changing environment is an important topic in the field of hydrological science. Increasing temperature and changes in precipitation pattern due to climate change are expected to alter regional hydrological conditions, affecting water resources availability and the discharge regime of rivers [1]. Changes in amount, intensity, and frequency of the precipitation will not only affect the magnitude of streamflow but will also alter the intensity and frequency of occurrence of extreme flood events [5,17]. Numerous studies have been conducted to determine how different factors impact streamflow generation. Water resources and river streamflow have been affected by climate variability and global warming. Hence, it is of great practical significance to study the response mechanism of hydrological process change for future water resource planning and management. The basin of Mahanadi is likely to experience severe flooding under the changing climate scenarios. The spatial and temporal variation of daily rainfall for 30 years over Mahanadi basin have been analyzed and the study concluded that the region experiences higher frequency and higher intensity of very heavy rainfall with less inter-annual variability [29]. Average annual rainfall here is $1572 \mathrm{~mm}$, of which $70 \%$ is precipitated during the south-west monsoon between June to October [30]. The basin is highly vulnerable to floods and has been affected by catastrophic flood disasters almost annually. The Mahanadi was notorious for its devastating floods for much of recorded history, and consequently it is called the "sorrow of Odisha" [30]. The problem of flooding still persists, and a lasting solution needs to be evolved. The Mahanadi belt is best known for its fertile soil and flourishing agriculture. The major portion of this river basin is agriculturally dominated (approximately 60\%) followed by forest area (approximately $25 \%$ ) mostly in the upper catchment [31]. Though agriculture is dominant in the basin, the economic background of the farmers is quite low here in comparison to the rest of the country as agriculture is heavily dependent on rainfall and the irregular and erratic nature of has damaged many of them. As hydrology plays an important role in determining the growth of agricultural sector; therefore, studying the impact of climate variability on hydrology [32-35] is a major issue of concern. Hence, the pivotal role of climate in agriculture sector, the principal source of livelihood of the population and 
low economic background of the farmers in and around the basin, motivated the authors to investigate the impact of climate variability on streamflow [36-39] in terms of various climatic parameters in the basin region.

Streamflow of the Mahanadi river basin is mainly dependent on seasonal monsoon rainfall. About $85 \%$ of total rainfall occurs in the Mahanadi basin during monsoon season only. The analysis of the Mahanadi basin using the predicted data for the period, 2041-2060, revealed that in future due to climate variability, severe flooding will occur in delta region causing destruction in low-lying areas [40,41]. Among various sources of recurring climate variability, ENSO (El Nino Southern Oscillation), ENSO Modoki, Indian Monsoon, and IOD (Indian Ocean Dipole) are supposed to have great influence on water streamflow of the Mahanadi river basin. Hence, the main objective of this study is to investigate the relative and combined effects of Indian Monsoon and Indo-Pacific climatic modes on high streamflow events and flood frequency analysis in the Mahanadi river basin.

\section{Study Area}

The Mahanadi river is one of the major interstate, east flowing rivers in peninsular India. The river flows through the states of Chhattisgarh and Odisha before it outfalls into the Bay of Bengal. The detail characteristics of the physiographic, hydrographic, meteorological and land use land cover conditions of the Mahanadi basin is described below:

\subsection{Physiography}

The Mahanadi basin has varying topography with the lowest elevation in coastal reaches and highest elevation found in northern hills. It is broadly divided into three subdivisions: Upper Mahanadi, Middle Mahanadi, and Coastal plains [42]. The Mahanadi upper sub basin with its predominant hilly terrain in its northern upper part has elevation range from 750 to $1000 \mathrm{~m}$. The area near upper reaches of the Mahanadi River has elevation between 500 and $750 \mathrm{~m}$. The central table land which divides the Mahanadi middle and lower sub basin has general elevation of 400-500 m. The Coastal plain covers the large delta by Mahanadi and elevation decreases towards this deltaic stretch reaching up to $10-50 \mathrm{~m}$ [43].

\subsection{Hydrography}

Mahanadi is one of the major east flowing peninsular rivers in India. The total length of the major channel of the river from origin to its outfall into the Bay of Bengal is $958.05 \mathrm{~km}$. The three major tributaries namely the Seonath and the Ib river on the Left Bank and the Tel on the Right Bank together constitute nearly $46.63 \%$ of the total catchment area of the river Mahanadi. The maximum streamflow observed during monsoon season from June to October [43].

\subsection{Meteorology}

The Mahanadi basin experiences four distinct seasons, namely the cold weather, the hot weather, the south-west monsoon, and the post monsoon. More than $90 \%$ of the total annual rainfall occurs during monsoon season spread over from June to October. The rainfall is not continuous but occurs in spells of varying durations and intensities.

\subsection{Land Use Land Cover}

To avoid anthropogenic impact like land use land cover impact on streamflow, we have taken upper catchment stream gauge station data for this study (Figure 1). As it is known that upper catchment of the Mahanadi basin is mostly forest cover [42].

To investigate the Indo-Pacific climate modes on streamflow we have taken four stream gauge stations of upper streams for the study, those are Andhiyarkore $\left(21^{\circ} 83^{\prime} \mathrm{N}, 81^{\circ} 6^{\prime} \mathrm{E}\right)$, Baronda $\left(20^{\circ} 91^{\prime} \mathrm{N}\right.$, $\left.81^{\circ} 88^{\prime} \mathrm{E}\right)$, Rajim $\left(20^{\circ} 97^{\prime} \mathrm{N}, 81^{\circ} 87^{\prime} \mathrm{E}\right)$, and Kesinga $\left(20^{\circ} 2^{\prime} \mathrm{N}, 83^{\circ} 22^{\prime} \mathrm{E}\right)$, (Figure 1). Among which 
three stations i.e., Andhiyarkore, Baronda, and Rajim are in the upper catchment and Kesinga lies in the lower catchment of the basin but upper streams as seen in Figure 1. Additionally, selection of the stations is based on the criteria that none of the stations are artificially regulated, to analyze the sensitivity of streamflow for extreme flood events.

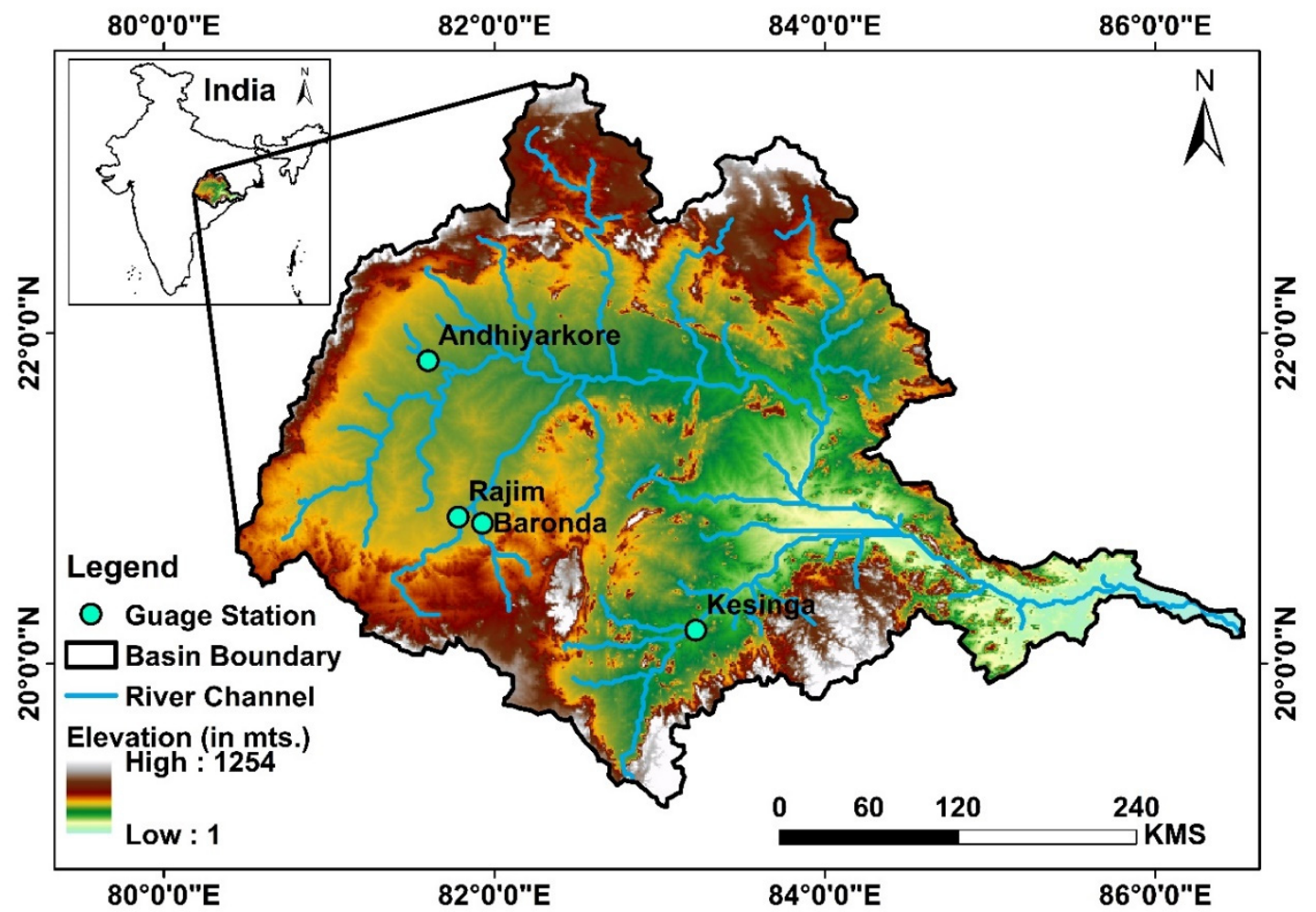

Figure 1. Location map of Andhiyarkore, Baronda, Rajim, and Kesinga streamgauge stations within the Mahanadi River basin.

\section{Data and Methods}

Before analyzing the data, the homogeneity test was done using XLSTAT software. Though there are various tests for homogeneity, we used SNHT (Standard Normal Homogeneity Test) in our study. It is a widely used technique and applied to a series of ratios that compare the observations of a measuring station with the average of other remaining stations and so on. As far as the result is concerned the computed " $p$ " value, i.e., 0.1 , which is greater than the "alpha value", i.e., 0.05 ; hence, the null hypothesis " $\mathrm{H0}$ " is accepted, which says the data are homogeneous [44].

Climatology and anomalies of streamflow were calculated on daily basis from 1980 to 2013 for 34 years in total. The daily streamflow data for the four selected stations (Andhiyarkore, Baronda, Rajim, and Kesinga) were obtained from the "India-WRIS (Water Resources Information System)" site. High streamflow events were picked from the daily streamflow anomaly data based on a threshold of $1.5 \sigma$ ( $\sigma$ stands for standard-deviation). Persistently high values for 6 days or more were combined to frame one extreme event. In addition to these, various climate indices were used to show the variability impact on daily streamflow like Monsoon Index (hereafter MI), El Nino Modoki Index (hereafter EMI), Oceanic Nino Index (hereafter ONI), Dipole Mode Index (hereafter DMI), and Nino3. Among various monsoon indices "Indian Summer Monsoon Index" is used, which is computed as follows:

$$
\mathrm{IM} \text { Index }=\mathrm{U} 850\left(40^{\circ} \mathrm{E}-80^{\circ} \mathrm{E}, 5^{\circ} \mathrm{N}-15^{\circ} \mathrm{N}\right)-\mathrm{U} 850\left(70^{\circ} \mathrm{E}-90^{\circ} \mathrm{E}, 20^{\circ} \mathrm{N}-30^{\circ} \mathrm{N}\right)
$$

is the means difference between $\mathrm{U} 850$ ( $\mathrm{U}$ wind at $850 \mathrm{mb}$ ) over two regions with varied latitudinal and longitudinal extension as mentioned in Equation (1), where IM stands for Indian Monsoon. 
EMI associated with El Nino Modoki (mEl Nino) and La Nina Modoki (mLa Nina) that influences the streamflow, was derived from Ashok et al. (2007). It is defined as mEL Nino (mLa Nina) with strong warming (cooling) in the central tropical pacific and cooling (warming) in the eastern and western tropical pacific $[45,46]$. This index is computed as:

$$
\mathrm{EMI}=\mathrm{SSTA}_{\text {box-A }}-0.5 \times \mathrm{SSTA}_{\text {box-B }}-0.5 \times \mathrm{SSTA}_{\text {box-C }}
$$

Sea surface temperature (SST) means the water temperature close to the surface of the ocean. SSTA means sea surface temperature anomaly, which is a departure of prevailing temperature from average conditions.

The boxes in Equation (2) represents SST anomalies over region A $\left(165^{\circ} \mathrm{E}-140^{\circ} \mathrm{W}, 10^{\circ} \mathrm{S}-10^{\circ} \mathrm{N}\right)$, $\mathrm{B}\left(110^{\circ} \mathrm{W}-70^{\circ} \mathrm{W}, 15^{\circ} \mathrm{S}-5^{\circ} \mathrm{N}\right)$, and $\mathrm{C}\left(125^{\circ} \mathrm{E}-145^{\circ} \mathrm{E}, 10^{\circ} \mathrm{S}-20^{\circ} \mathrm{N}\right)$, respectively [46].

ONI, believed to have strong impact on streamflow, is National Oceanic and Atmospheric Administrations (NOAA) primary index for monitoring the relative strength of El Nino Southern Oscillation (ENSO). It is related to strong anomalous warming/cooling condition in eastern tropical pacific and cooling/warming condition in western tropical pacific. It is calculated as taking the three-month running average ERSST.V4 (Extended Reconstruction SST. Version 4) SST anomalies in the Nino $3.4\left(5^{\circ} \mathrm{N}-5^{\circ} \mathrm{S}, 120^{\circ} \mathrm{W}-170^{\circ} \mathrm{W}\right)$ region.

DMI is used to represent the intensity of Indian Ocean Dipole by anomalous SST gradient between the western $\left(50^{\circ} \mathrm{E}-70^{\circ} \mathrm{E}\right.$ and $\left.10^{\circ} \mathrm{S}-10^{\circ} \mathrm{N}\right)$ tropical Indian Ocean and the eastern $\left(90^{\circ} \mathrm{E}-110^{\circ} \mathrm{E}\right.$ and $10^{\circ} \mathrm{S}-0^{\circ}$ ) tropical Indian Ocean [47]. A positive IOD (pIOD) phenomenon is described as the cooler than normal water in the tropical eastern Indian Ocean and warmer than normal water in the tropical western Indian Ocean whereas a negative IOD is identified as warmer than normal water in tropical eastern Indian Ocean and cooler than normal water in western Indian Ocean [48].

Nino3 index is calculated by taking area average of SST anomalies in ${ }^{\circ} \mathrm{C}$ (degree Celsius) of region over eastern Pacific Ocean which is bounded by $90^{\circ} \mathrm{W}-150^{\circ} \mathrm{W}$ and $5^{\circ} \mathrm{S}-5^{\circ} \mathrm{N}$.

To establish the relationship between streamflow and various climate parameters, correlation and partial correlation techniques were used. We used Pearson's product moment correlation technique for the study. While correlation techniques establish a mutual association between two variables, partial correlation took place to find out the variable which had the most determining effect. Then partial correlation was conducted, being the relationship between two variables while controlling a third variable, because the third variable has shown a relationship to one or both of the primary variables.

Stepwise regression is a method of fitting regression models in which the choice of predictive variables is carried out by an automatic procedure. In each step, a variable is considered for addition to, or subtraction from, the set of explanatory variables based on some prespecified criterion. Among various approaches of stepwise regression analysis, backward elimination procedure was used in this calculation. This involved starting with all candidate variables, testing the deletion of each variable using a chosen model fit criterion, deleting the variable (if any) whose loss gives the most statistically insignificant deterioration of the model fit, and repeating this process until no further variables can be deleted without a statistically significant loss of fit. Though stepwise regression analysis was carried for all variables only the significant results were used in the study for analysis.

After analyzing the streamflow sensitivity to extreme flood events, we extended our analysis to the frequency distribution, Weibull's plotting position method was used to compute the 34 years return period to identify the flood frequency within the Mahanadi river basin for policy makers and water managers. We assumed that the data followed a specific distribution (Gumbel or Extreme Value Type 1) (see Section 4.5). We estimated the parameters of the distribution by using following cumulative distribution function (CDF):

$$
p(x)=\exp \left\{-\exp \left[-\frac{1}{\alpha}(x-\mu)\right]\right\}
$$


where $x$ is the observed maxima, $\mu$ and $\alpha$ are location parameters, respectively, and computed as

$$
\begin{gathered}
\mu=\bar{x}-0.5772 \alpha \\
\alpha=\frac{\sqrt{6}}{\pi} s_{x}
\end{gathered}
$$

(Here, $\bar{x}$ and $s_{x}$ are the mean and standard deviation, respectively.)

\section{Results and Discussion}

\subsection{Seasonality of Daily Streamflow}

The daily climatology of the Mahanadi streamflows (Figure 2) showed higher seasonal flows during the months of June-November and very less streamflow was experienced in the basin after October, i.e., from November to May (figure not shown) in all four stations. As already mentioned in the introduction, the Mahanadi is a monsoon led river, monsoonal rainfall feeds the streamflow of the basin. Monsoon starts in June and lasts till September in the Indian sub-continent. Hence, it is also clearly visible from the figure that high streamflow took place around mid-June and got lower by mid-September. The four stream gauge stations showed almost same pattern of seasonal climatology. To extract the high streamflow events, $1.5 \sigma$ threshold was applied, and persistence of seven days or more was considered as one event. The peak streamflows were observed during monsoonal months which resulted into floods. Panda et al. [49] in their study observed that the Mahanadi basin is characterized by a tropical monsoon (June to September) climate and more than $80 \%$ of the annual runoff occurs during the monsoon season. Moreover, these high streamflow events or floods [50,51] have a tremendous impact on the local population and ecosystem. Hence, to cope with this obvious impact of floods in the basin area, the study of climate variability impact on river water streamflow has become the need of the hour.

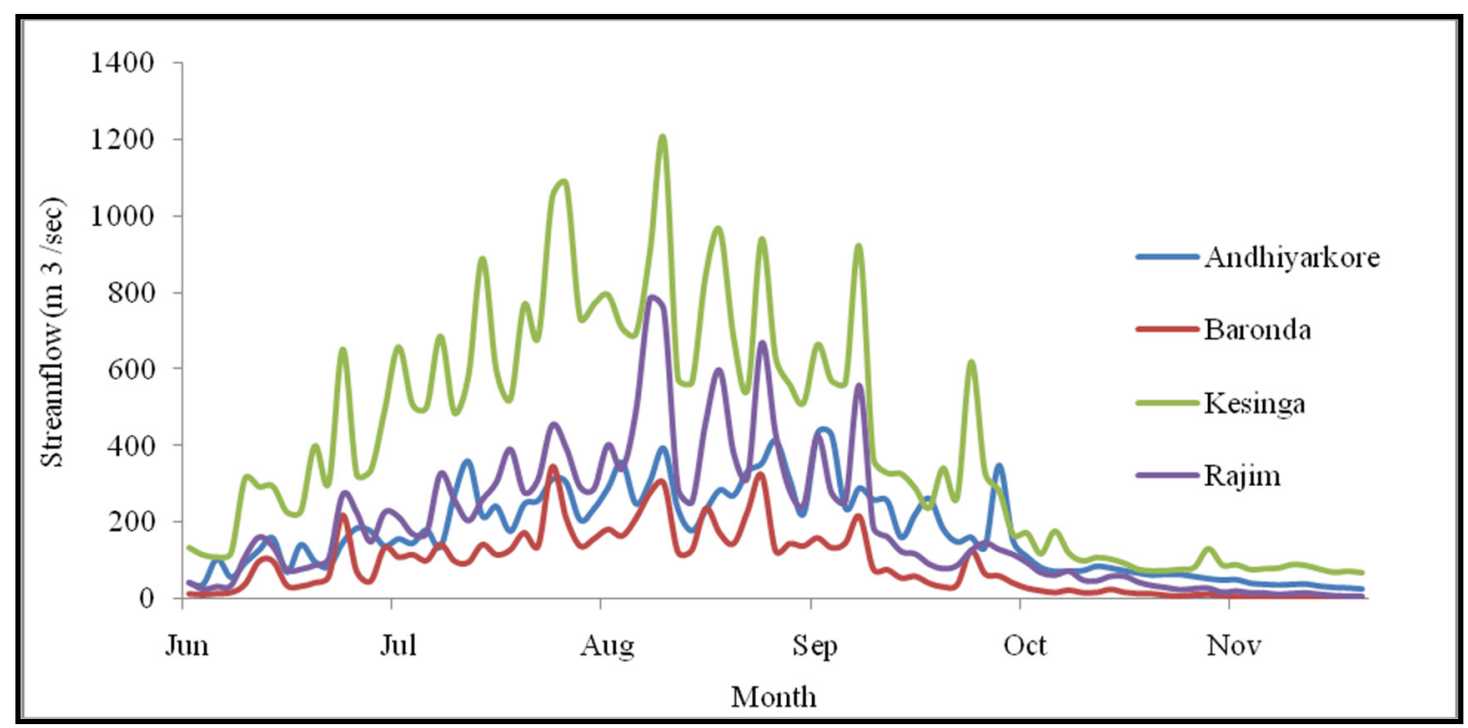

Figure 2. The daily streamflow climatology at four selected stations (1980-2013), Andhiyarkore (blue), Baronda (red), Rajim (violet), and Kesinga (green).

As shown in Tables 1-4 the high streamflow events were calculated by taking into account the persistence flow for seven days or more, for all four stations separately during the JJA and SON seasons. The results display maximum dominance of Indian Monsoon on high streamflow events or flood events. Along with Indian Monsoon, La Nina, La Nina Modoki (mLa Nina), the positive Indian Ocean Dipole also has a significant role in influencing a high streamflow event. 
Table 1. The extreme high streamflow events at Andhiyarkore station for June, July, and August (JJA) and September, October, and November (SON) seasons, where each event is selected from the persistence occurrence of high flows for 6 days or more (1980-2013). pIOD in table is positive IOD.

\begin{tabular}{ccc}
\hline Seasons & Event Years & Start and End Day of Each Event \\
\hline \multirow{3}{*}{ JJA } & 1990 (Indian Monsoon) & 26 June-05 July \\
\cline { 2 - 3 } & 1994 (Indian Monsoon) & 8 July-18 July \\
\cline { 2 - 3 } & 2006 (Indian Monsoon) & 29 May-6 June \\
\hline \multirow{2}{*}{1990 (Indian Monsoon) } & 22 September-28 September \\
\cline { 2 - 3 } & 1994 (Indian Monsoon) & 12 October-18 October \\
\cline { 2 - 3 } SON & 1998(pIOD) & 2 November-19 November \\
\cline { 2 - 3 } & 2003 (Indian Monsoon) & 22 November-30 November \\
\cline { 2 - 3 } & 2013 (Indian Monsoon) & 10 October-22 October \\
\cline { 2 - 3 } & & 24 October-30 November \\
\hline
\end{tabular}

IOD-Indian Ocean Dipole.

Table 2. The extreme high streamflow events at Baronda station for JJA and SON seasons, where each event is selected from the persistence occurrence of high flows for 6 days or more (1980-2013).

\begin{tabular}{ccc}
\hline Seasons & Event Years & Start and End Day of Each Event \\
\hline \multirow{3}{*}{ JJA } & 1984 (Indian Monsoon, pIOD) & 30 May-8 June \\
\cline { 2 - 3 } & 2001 (Indian Monsoon, La Nina) & 6 June-16 June \\
\cline { 2 - 3 } & $2007(\mathrm{pIOD})$ & 27 June-3 July \\
\hline \multirow{2}{*}{ SON } & $1987(\mathrm{pIOD})$ & 19 November-26 November \\
\cline { 2 - 3 } & 1990 (Indian Monsoon) & 1 October-18 October \\
\cline { 2 - 3 } & 1998 (mLa Nina) & 22 November-18 November \\
\cline { 2 - 3 } & 2003 (Indian Monsoon) & 20 October-8 November \\
\hline & 2013 (Indian Monsoon) & 23 November-29 November \\
\hline
\end{tabular}

Table 3. The extreme high streamflow events at Rajim station for JJA and SON seasons, where each event is selected from the persistence occurrence of high flows for 6 days or more (1980-2013).

\begin{tabular}{|c|c|c|}
\hline Seasons & Event Years & Start and End Day of Each Event \\
\hline \multirow{3}{*}{ JJA } & 1986 (mLa Nina) & 21 June-29 June \\
\hline & 2000 (Indian Monsoon, La Nina) & 3 June-12 June \\
\hline & 2004 (Indian Monsoon) & 15 June-21 June \\
\hline \multirow{9}{*}{ SON } & 1986 (mLa Nina) & 13 November-19 November \\
\hline & 1987 (pIOD) & 19 November-29 November \\
\hline & \multirow{3}{*}{1990 (Indian Monsoon) } & 1 October-8 October \\
\hline & & 10 October-23 October \\
\hline & & 7 November-18 November \\
\hline & 1994 (Indian Monsoon) & 30 August-6 September \\
\hline & \multirow{2}{*}{2003 (Indian Monsoon) } & 25 September-3 October \\
\hline & & 21 October-11 November \\
\hline & 2013 (Indian Monsoon) & 30 September -5 October \\
\hline
\end{tabular}


Table 4. The extreme high streamflow events at Kesinga station for JJA and SON seasons, where each event is selected from the persistence occurrence of high flows for 6 days or more (1980-2013).

\begin{tabular}{|c|c|c|}
\hline Seasons & Event Years & Start and End Day of Each Event \\
\hline \multirow{7}{*}{ JJA } & 1995 (pIOD) & 20 July-25 July \\
\hline & \multirow{2}{*}{2001 (La Nina) } & 21 May-17 June \\
\hline & & 5 July-12 July \\
\hline & \multirow{2}{*}{2006 (Indian Monsoon) } & 17 May-3 June \\
\hline & & 6 June-12 June \\
\hline & 2007 (pIOD) & 22 May-5 June \\
\hline & 2010 (pIOD) & 31 May-8 June \\
\hline \multirow{7}{*}{$\mathrm{SON}$} & 1987 (pIOD) & 10 November-16 November \\
\hline & \multirow{2}{*}{1990 (Indian Monsoon) } & 11 October-19 October \\
\hline & & 5 November-12 November \\
\hline & 2005 (Indian Monsoon) & 24 October-5 November \\
\hline & 2006 (Indian Monsoon) & 10 November-19 November \\
\hline & 2008 (La Nina) & 21 November-30 November \\
\hline & 2011 (La Nina) & 20 September-26 September \\
\hline
\end{tabular}

\subsection{Impact of Indian Monsoon}

Monsoon plays a pivotal role in streamflow variability of the Mahanadi river basin. As it is a monsoon fed river, it faces heavy streamflow during the monsoon season, that is from June to September. Therefore, the correlation (values shown in Tables 5 and 6) of streamflow anomalies with Monsoon Index were calculated for the JJA season and the SON season to quantify the impact of this climatic variability mode (Indian Monsoon). Pearson's correlation coefficient calculation was followed to study the variability impact. An important thing to be mentioned here is that, while calculating correlation, the MI of the JJA season was taken into consideration with streamflow anomalies of the JJA season, but for the SON season, the MI of both the JAS and June, July, August and September (JJAS) seasons were taken into account for calculating Pearson's correlation with streamflow anomalies of the SON season as the MI for the SON season was not available.

Table 5. Correlation coefficients and partial correlation coefficients of the Monsoon Index (MI) and the El Nino Modoki Index (EMI) with streamflow anomaly in the JJA season. It should be noted that for partial correlation calculation between river-streamflow and MI, the influence of EMI was excluded, and same process was done to EMI. Coefficient values are statistically significant at $95 \%$ level with two-tailed student's t-test.

\begin{tabular}{ccccc}
\hline \multirow{2}{*}{ Stations } & \multicolumn{2}{c}{ Correlation } & \multicolumn{2}{c}{ Partial Correlation } \\
\cline { 2 - 5 } & MI & EMI & MI & EMI \\
\hline Andhiyarkore & 0.53 & 0.37 & 0.423 & 0.33 \\
Baronda & 0.38 & 0.42 & 0.22 & -0.28 \\
Rajim & 0.44 & 0.51 & -0.2 & 0.59 \\
Kesinga & 0.38 & 0.36 & -0.72 & 0.43 \\
\hline
\end{tabular}

For calculating partial correlation, EMI was into consideration with MI, because it displayed high correlation with streamflow anomaly during these seasons. Hence, to measure the strength of Indian Monsoon, the effect of EMI was controlled. Based on the result, it was found that all station displayed a significant positive correlation with Indian Monsoon. The correlation values for Andhiyarkore, Baronda, Rajim, and Kesinga, during the JJA season, are $0.53,0.38,0.44$, and 0.38 , respectively. Similarly, 
with EMI, the streamflow also shows strong positive correlation, i.e., 0.37 for Andhiyarkore, 0.42 for Baronda, 0.51 for Rajim, and 0.36 for Kesinga. As far as partial correlation is concerned, only streamflow at Rajim and Kesinga stations showed negative correlation with MI, i.e., -0.2 and -0.72 , respectively. This indicates the strong influence of EMI on the streamflow of these two stations. A similar thing was found with Baronda station when partial correlation of streamflow with EMI was calculated, the result was found to be -0.28 . It undermines the impact of EMI on the streamflow at Baronda station.

Table 6. Correlation coefficients of SON streamflow anomaly and the MI of JJA, JJAS, and JAS.

\begin{tabular}{cccc}
\hline \multirow{2}{*}{ Stations } & \multicolumn{3}{c}{ Correlation } \\
\cline { 2 - 4 } & MI-JJA & MI-JJAS & MI-JAS \\
\hline Andhiyarkore & 0.23 & 0.40 & 0.37 \\
Baronda & 0.19 & 0.21 & 0.20 \\
Rajim & 0.23 & 0.25 & 0.24 \\
Kesinga & -0.14 & -0.11 & -0.07 \\
\hline
\end{tabular}

The impact of Indian Monsoon was proved from correlation and partial correlation values displayed in Tables 5 and 6. Apart from climate factors, land use and land cover need to be studied for the quality of water, as argued by Jun, and Wang and Hejazi [13,52], for better management of water resources in a basin.

\subsection{Impact of Indo-Pacific Climate Variability Modes}

Other than Indian Monsoon, the study also attempts to understand the regional manifestation of Indo-Pacific climate impacts, because it is well known that the Indo-Pacific climate largely influences large-scale phenomenon such as monsoons. It can be said that the strength of Indian Monsoon, whether strong or weak, largely depends on the nature of Indo-Pacific climate variability parameters. Therefore, the relationship between river streamflow and climate variation are very important since the latter has a direct influence on Monsoon as well as on rainfall variability.

To quantify and show the extent of impact of Indo-Pacific variability modes, partial correlation was calculated between streamflow anomalies during the JJA season and ONI, EMI, and Nino3 of the NDJ (November-January), DJF (December-February), and JFM (January-March) seasons, respectively (Figure 3), and DMI of the SON (September-November) and OND (October-December) seasons, respectively (Table 7 ).

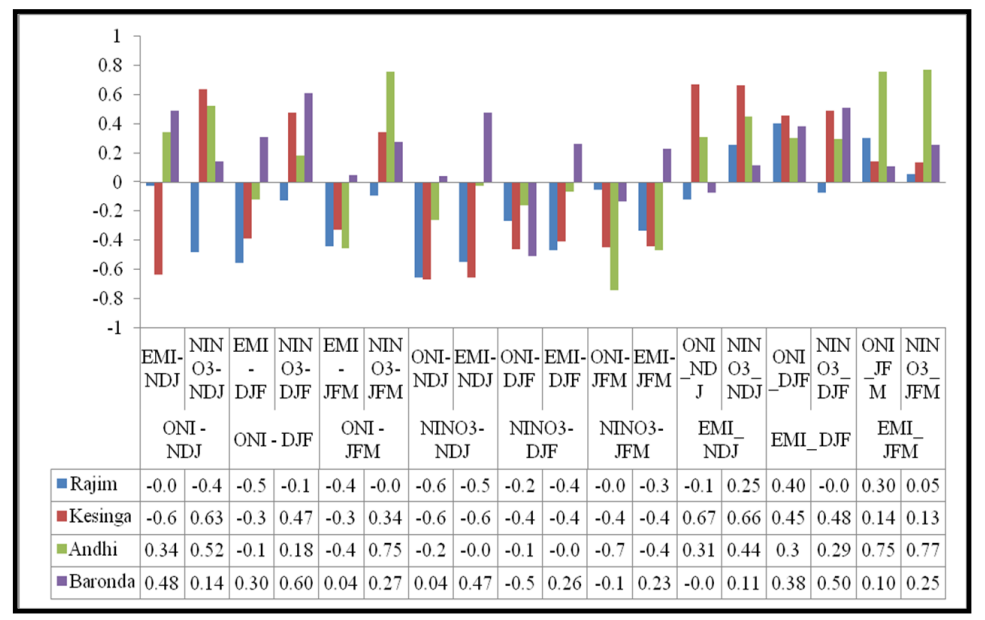

Figure 3. Partial correlation of Oceanic Nino Index (ONI), EMI and Nino3 with streamflow anomalies at four selected stations in JJA season. Here it is to be noted that partial correlation between streamflow and ONI has excluded the influence of EMI and Nino3. The same process was done to EMI and Nino3. 
Table 7. Partial correlation of streamflow anomaly of the JJA season with Dipole Mode Index (DMI) of the SON and the October-December (OND) season.

\begin{tabular}{cccccc}
\hline Climate Index & $\begin{array}{c}\text { Controlled } \\
\text { Variable }\end{array}$ & Andhiyarkore & Baronda & Rajim & Kesinga \\
\hline \multirow{3}{*}{ DMI_SON } & EMI_SON & -0.458 & -0.675 & -0.106 & 0.268 \\
& ONI_SON & -0.218 & -0.651 & -0.38 & -0.275 \\
& Nino3_SON & 0.204 & -0.551 & -0.22 & -0.778 \\
\hline \multirow{3}{*}{ DMI_OND } & EMI_OND & 0.51 & -0.722 & -0.094 & 0.297 \\
& ONI_OND & 0.445 & -0.59 & -0.412 & -0.149 \\
& Nino3_OND & 0.672 & -0.394 & -0.275 & -0.578 \\
\hline
\end{tabular}

Similarly, partial correlation values between streamflow anomalies of the SON season and climate variability indices, i.e., ONI, EMI, Nino3, and DMI of the SON season are displayed (see Figure 4). It is noteworthy to mention here that the partial correlation was calculated between event specific years and climate variability indices of previous years for the JJA season because climatic phenomena in the Pacific Ocean are in their peak occurrence during this time period, i.e., November-March. Hence, to show the impact of an El Nino or La Nina event on streamflow in Mahanadi Basin, partial correlation was calculated. Likewise, Indian Ocean Dipole has its occurrence in the Indian Ocean during the SON and OND seasons. Hence, to see the effect of IOD on high streamflow event in the basin, DMI of $\mathrm{SON}$ and OND was taken into consideration. However, while calculating partial correlation between streamflow anomaly of the SON season and climate variability modes, the index values of same year were taken.

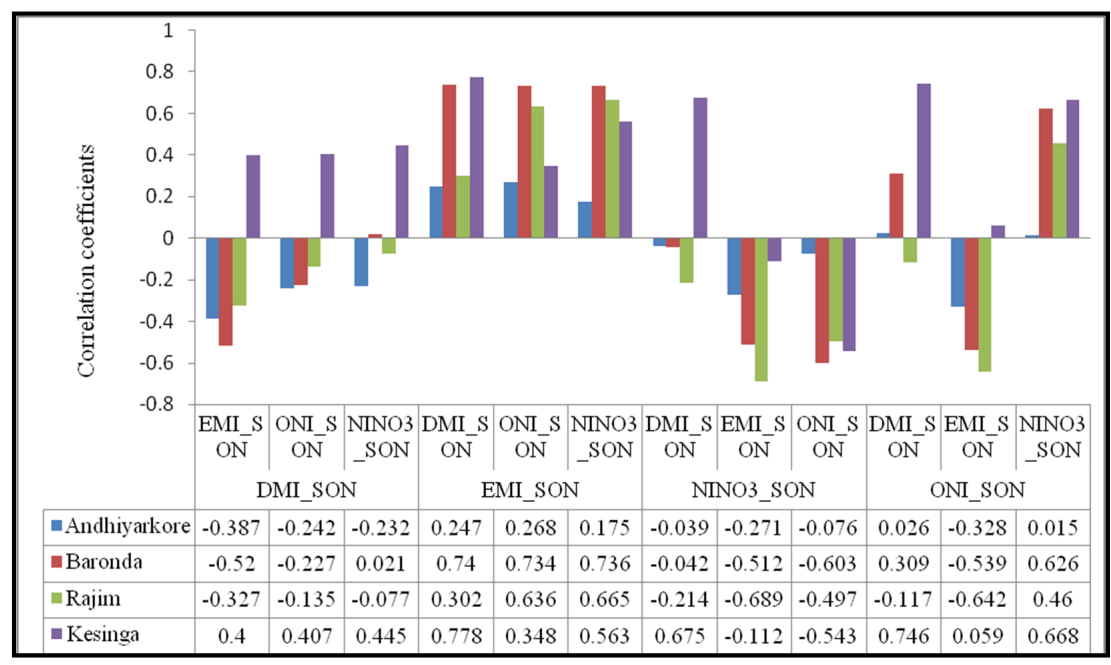

Figure 4. Partial correlation of ONI, EMI, DMI and Nino3 with streamflow anomalies at four selected stations for the SON season. Here, it is to be noted that partial correlation between streamflow and ONI has excluded the influence of DMI, EMI, and Nino3. Same process was done to DMI, EMI, and Nino3.

The link between streamflow of JJA and SON seasons and global climatic variability modes (ONI, Nino3, EMI, and DMI) is shown through Figures 3 and 4 and Table 7. The results show the impact of global climate variability modes on the streamflow of Mahanadi Basin. Because of the proximity to coast of the Bay of Bengal, the Mahanadi river basin is sensitive to the large-scale coupled atmospheric-oceanic circulation modes such as the El Nino Southern Oscillation (ENSO) and Indian Ocean Dipole (IOD) [53]. In the study of Maity et al. [54], it was observed that both large scale global atmospheric inputs owing to hydroclimatic teleconnection and local inputs feature as important inputs in streamflow prediction of this basin. Hence, from our results, it was also confirmed that Indian 
monsoon affects streamflow the most, and that the basin experiences a moderate impact of global climatic variables.

\subsection{Stepwise Regression Analysis for Four Stations}

Stepwise regression is a method of fitting regression models [55] in which the choice of predictive variables is carried out by an automatic procedure. In each step, a variable is considered for addition to, or subtraction from, the set of explanatory variables based on some pre-specified criterion. This method evaluates the independent variable at each step, adding or deleting them from model. Hence, in this study, stepwise regression analysis with backward elimination method was incorporated to choose the best predictor for streamflow of four different stations in both the seasons, i.e., JJA and SON (Figure 5a,b and Figure $6 a, b)$. Four values have been presented in both the figures those are $R, R^{2}$, Beta, and Sig. " $R$ " value refers to the correlation value, where $R^{2}$ implies to the coefficient of determination, Beta is the correlation coefficient range from $0-1$, finally, the significance value suggests the strength of the test. It was found that MI-JJA proved to be the best predictor among MI-JJA, MI-JJAS, and MI-JAS, for streamflow of the JJA season in four stations. However, for the SON season, MI-JJAS played the role of best predictor in four studied stations. Likewise, when EMI, ONI, and Nino3, of NDJ and DJF were taken as independent variables to predict JJA streamflow of four stations, then it was found that EMI-NDJ was the best predictor for Andhiyarkore, Baronda, and Rajim stations, and that EMI-DJF was the best predictor for Kesinga season. For the SON season EMI-DJF played a dominant role for streamflow prediction of Andhiyarkore, Baronda, and Rajim stations, but ONI-DJF proved to be the dominant factor in predicting Kesinga station.

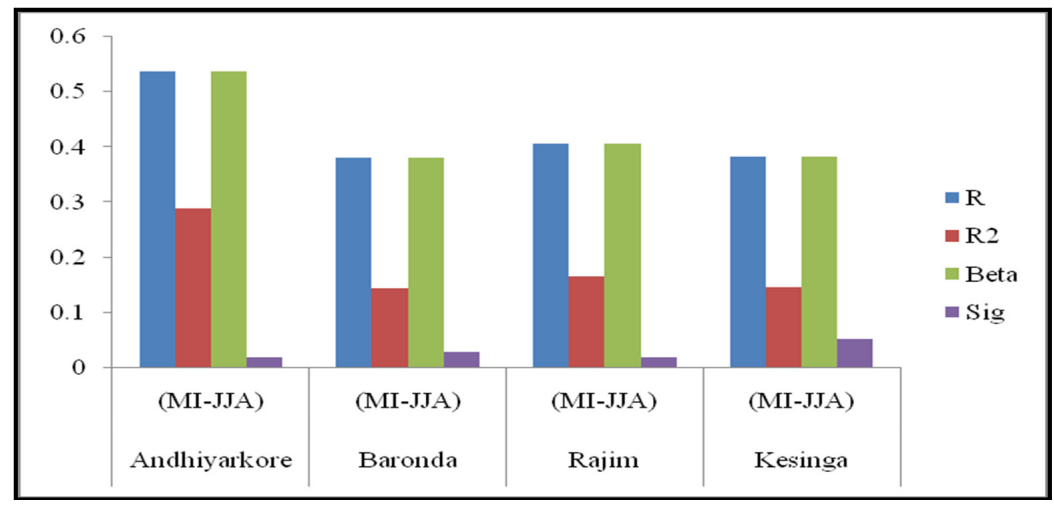

(a)

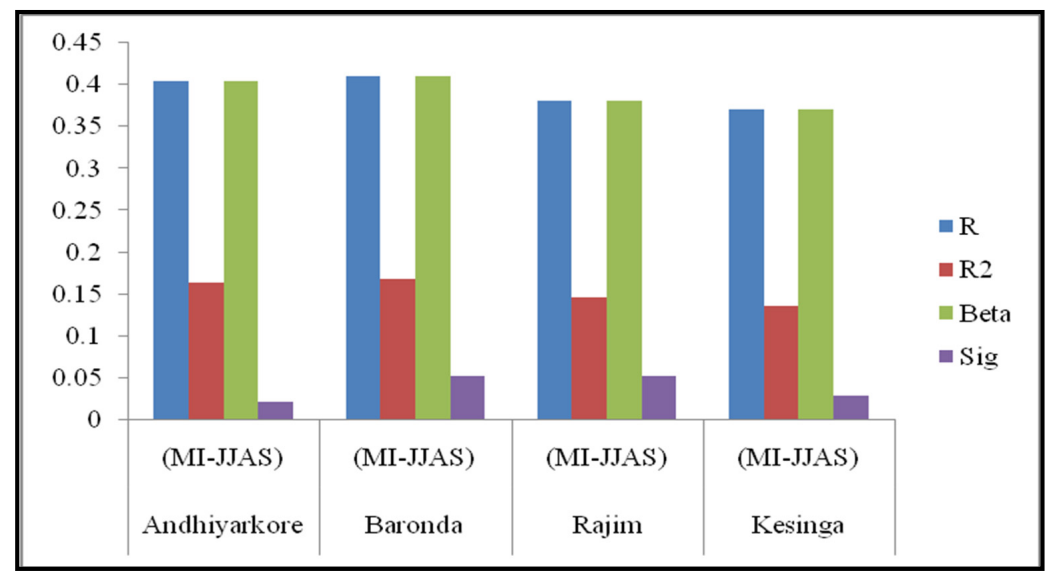

(b)

Figure 5. (a) Stepwise regression analysis for JJA season, taking MI-JJA, MI-JJAS, and MI-JAS as the independent variables; (b) Stepwise regression analysis for SON season taking MI-JJA, MI-JJAS, and MI-JAS as the independent variables. 


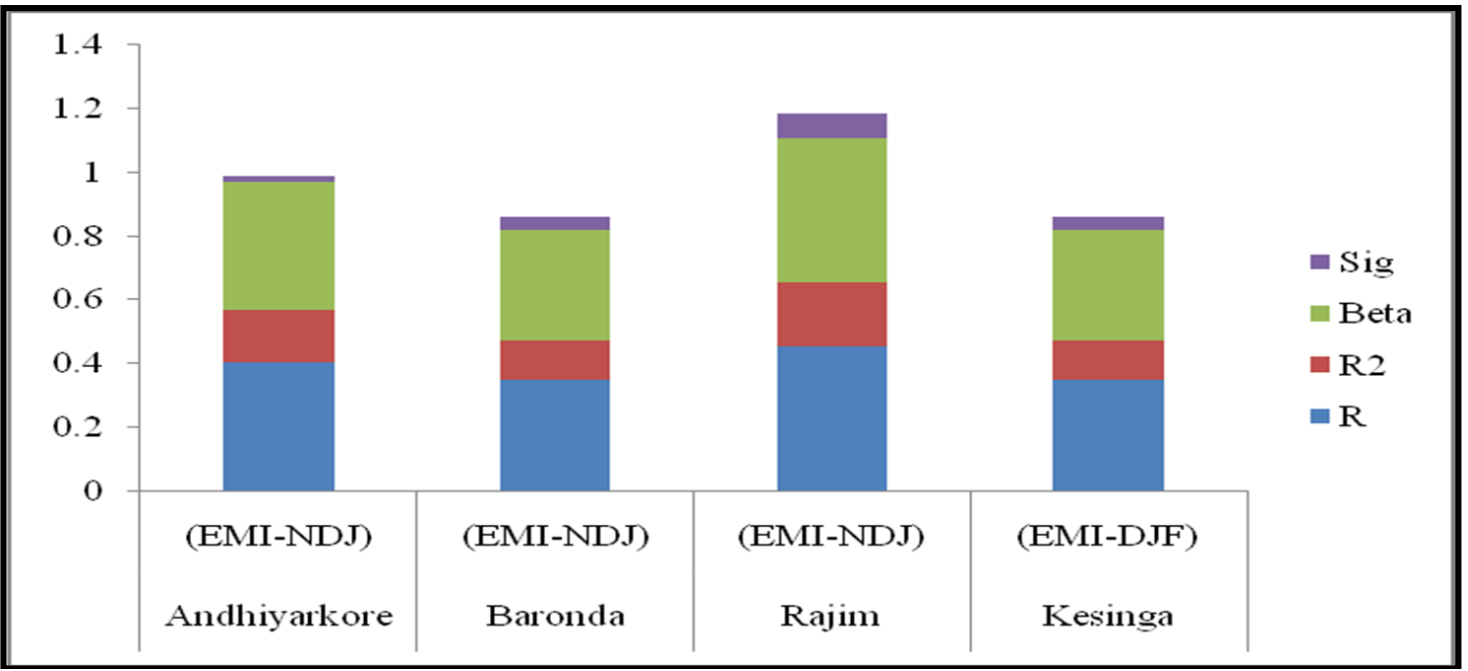

(a)

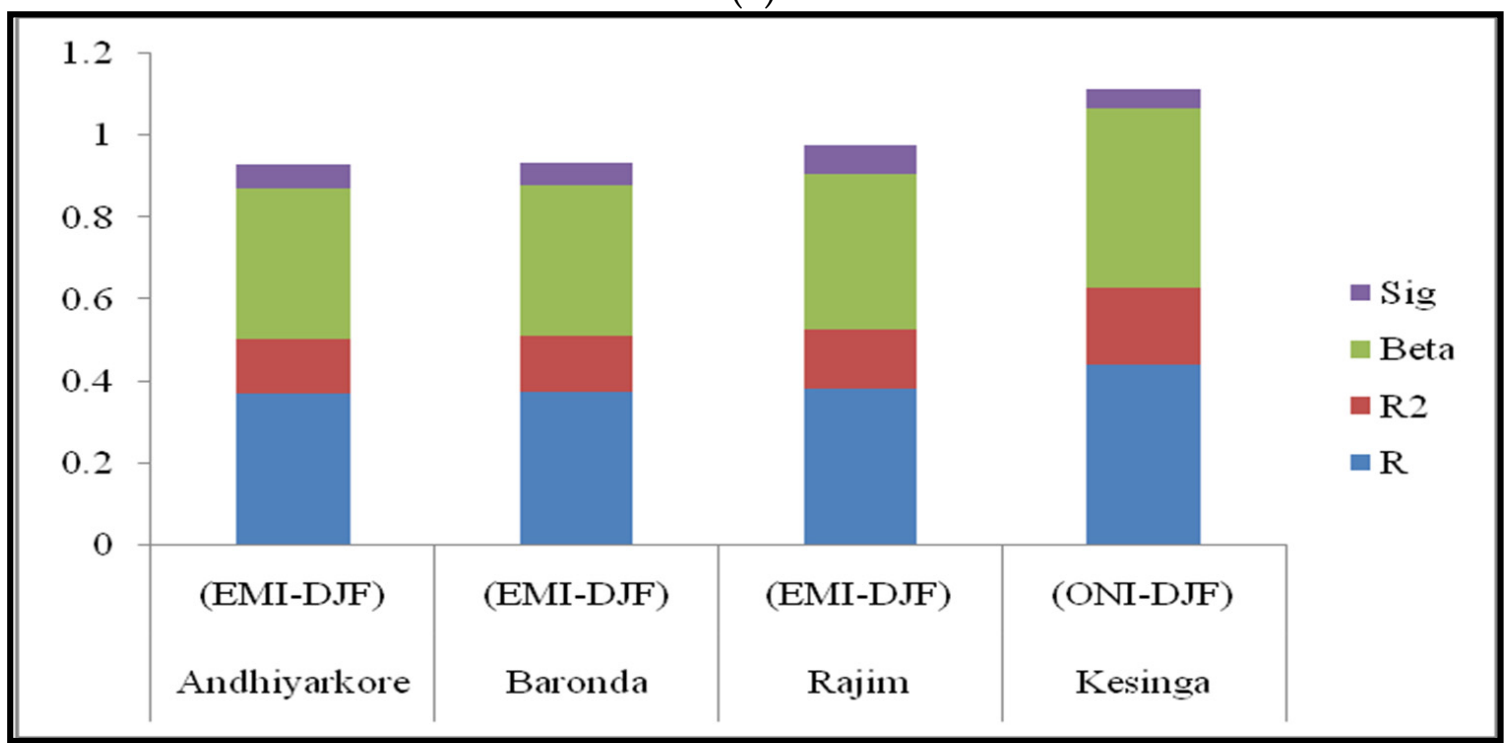

(b)

Figure 6. (a) Stepwise regression analysis for JJA season considering EMI, ONI, and Nino3 indices of the November-January (NDJ) and December-February (DJF) seasons as the independent variables; (b) Stepwise regression analysis for SON season considering EMI, ONI, and Nino3 indices of NDJ and DJF season as the independent variables.

\subsection{Flood Frequency Analysis}

We extended our analysis to the frequency distribution and return period of the streamflow with annual JJA and SON maximum streamflow values from the observation datasets for the period 1980-2013 (34 years). Many recent studies have highlighted that the flood events mostly exhibit a better fit with a specific distribution of Gumbel or Extreme Value Type 1. We assumed that the data followed a specific distribution (Gumbel or Extreme Value Type 1) [56-58]. Figure 7 shows the frequency distribution of annual JJA and SON daily maximum streamflow with respect to Gumbel distribution over four river areas, viz., Andhiyarkore (Figure 7a), Bronda (Figure 7b), Kesinga (Figure 7c), and Rajim (Figure 7d). We found that the probabilities of streamflow values exceeding $2000 \mathrm{~m}^{3} \mathrm{~s}^{-1}$ were higher in JJA at the Bronda, Kesinga, and Rajim river areas, while that of lower to $\sim 2000 \mathrm{~m}^{3} \mathrm{~s}^{-1}$ were higher in SON (Figure $7 \mathrm{~b}-\mathrm{d}$ ). The streamflow values at the Andhiyarkore river area were likely to have less runoff $\left(\sim 450 \mathrm{~m}^{3} \mathrm{~s}^{-1}\right.$ maximum in JJA and $\sim 1000 \mathrm{~m}^{3} \mathrm{~s}^{-1}$ in SON$)$, very small catchment, and located at 
higher elevation, as shown in Figure 1 (Figure 7a). However, the occurrence of streamflow in the range between about 50-320 $\mathrm{m}^{3} \mathrm{~s}^{-1}$ was higher in JJA compared to that of in SON.

(a) Frequency Distribution (ANDHIYARKORE)

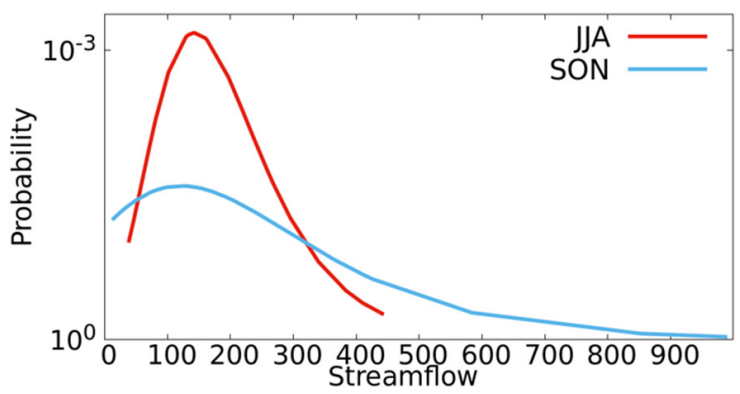

(c) Frequency Distribution (KESINGA)

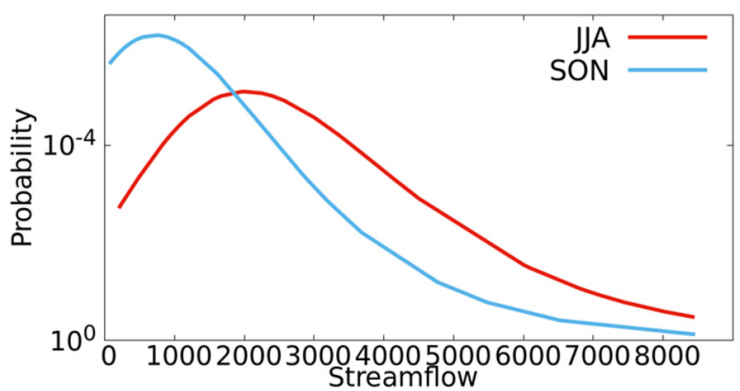

(b) Frequency Distribution (BARONDA)

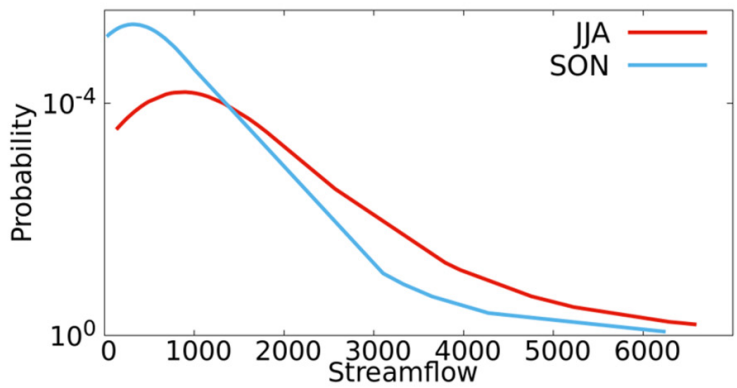

(d) Frequency Distribution (RAJIM)

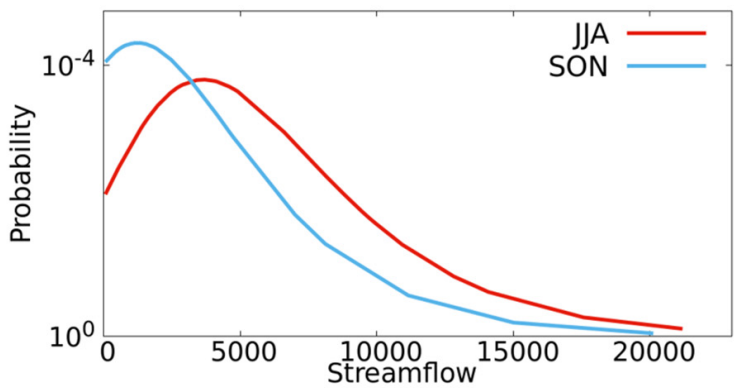

Figure 7. Frequency of annual JJA and SON maximum streamflow $\left(\mathrm{m}^{3} \mathrm{~s}^{-1}\right)$ with respect to Gumbel distribution.

Weibull's plotting position method along with Gumbel distribution was used to compute the return period and the results are shown in Figure 8. The return period obtained from Weibull's plotting position is referred as "estimated" and that from Gumbel distribution is referred as "theoretical". Results indicate that the return periods of streamflow values below $\sim 400 \mathrm{~m}^{3} \mathrm{~s}^{-1}$ are within 10 years at Andhiyarkore river areas in both JJA and SON, while that of higher values are within 34 years, although their occurrence are less (Figure 8a). The return period of streamflow at the Baronda, Kesinga, and Rajim river areas are noticed to be faster in JJA compare to that of in SON (Figure 8b-d). The 10 years return period of streamflow at the Baronda river area in SON corresponds to the value $\sim 3500 \mathrm{~m}^{3} \mathrm{~s}^{-1}$, while that of in JJA corresponds to the value $\sim 5000 \mathrm{~m}^{3} \mathrm{~s}^{-1}$ (Figure $8 \mathrm{~b}$ ). Similar characteristics with higher streamflow values are noticed at the Kesinga and Rajim river areas.

Overall, the return periods of streamflow in JJA shows robust results in both the estimations (Weibull and Gumbell), while in SON they show deviations after 10 years. The higher streamflow was found to have occurred more frequently in JJA at Bronda, Kesinga, and Rajim stations and their return periods are expected to be faster in JJA, indicating more floods in JJA over the Mahanadi river basin during monsoon season. The reason could be associated with the summer time warming over India which would increase the moisture holding capacity in the atmosphere according to the Clausius-Clapeyron relationship (7\% per degree rise in temperature) and may lead to more rainfall over the region [59-61] 
(a) Return Preriod (ANDHIYARKORE)

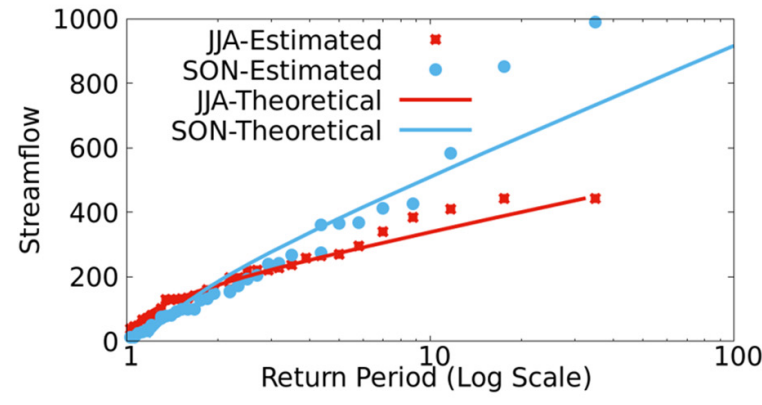

(c) Return Preriod (KESINGA)

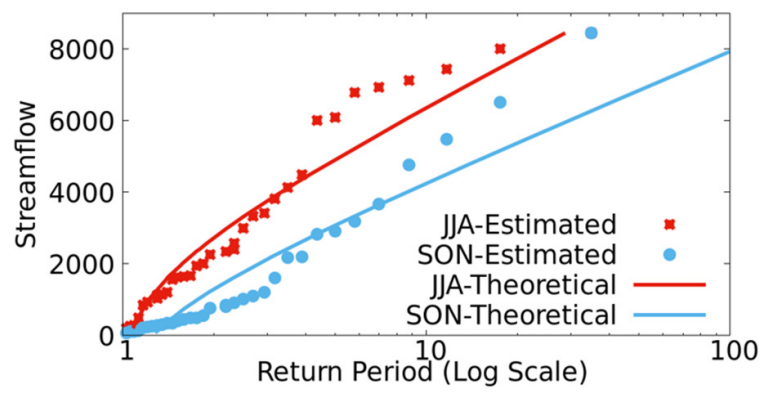

(b) Return Preriod (BARONDA)

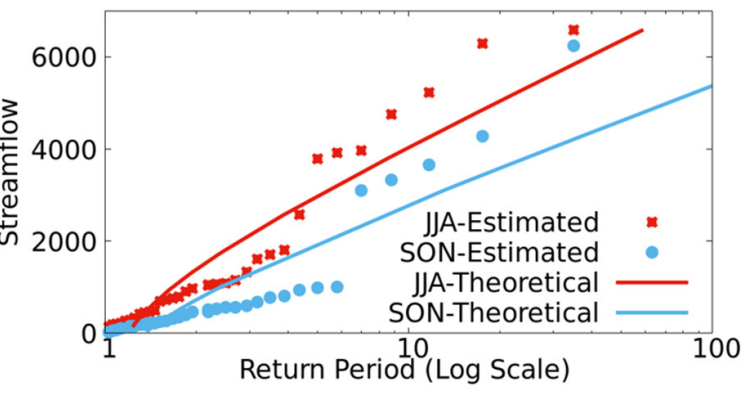

(d) Return Preriod (RAJIM)

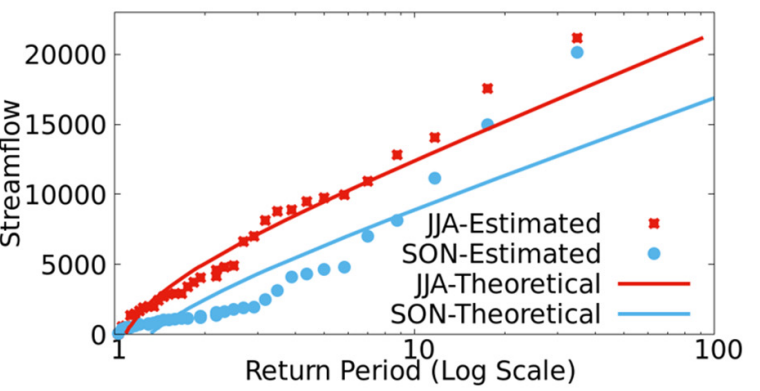

Figure 8. Return period of annual JJA and SON maximum streamflow $\left(\mathrm{m}^{3} \mathrm{~s}^{-1}\right)$ with respect to Weibull plotting position (estimated) and Gumbel distribution (theoretical).

\section{Conclusions}

Anomalous coupled ocean-atmosphere phenomena generated in the tropical oceans produce global atmospheric and oceanic circulation changes that influence regional climate conditions even in remote regions and eventually regional hydrology. In this study, the daily river streamflow characteristics with the climate variability, e.g., IOD, ENSO, ENSO Modoki, Indian Monsoon, and NINO3 were analyzed. Here, peak streamflow seasons (June-November) were taken into consideration for four gauge stations (Andhiyarkore, Baronda, Rajim, and Kesinga) of the Mahanadi river basin. The results show the stronger influences of Indian Monsoon on the extreme high streamflow events during the JJA and SON seasons. The impact of ENSO and ENSO Modoki on river extremities were also found to be significant during these two continuous seasons. Additionally, prevalence of positive IOD during event years were noticed. Since most of the climate variations in the Indo-Pacific sector are predictable on seasonal to inter-annual scales, the regional impacts of those, like direct influence on Indian monsoon and vis-a-vis on streamflow can be made beforehand. Moreover, these predictions can be extended to help the local communities dependent on streamflow. It has been found that among various indices of MI, MI-JJA has a determining effect for the streamflow of the JJA season and MI-JJAS has the dominant role in determining SON streamflow. Likewise, when stepwise regression model was calculated using the EMI, ONI, and Nino3 indices, then EMI of both NDJ and DJF play vital roles among all pacific climate variability modes in affecting streamflow of Mahanadi during the JJA and SON seasons. Furthermore, flood frequency analysis at Baronda, Kesinga, and Rajim were higher in JJA compared to SON. Return period indicates more floods in JJA over the Mahanadi river basin.

In addition to the societal impact, this study can be used to attract the attention of the climate and hydrology research groups to investigate those climatic links further. This study clearly displays the direct impact of Indian Monsoon and other Indo-Pacific climatic variability phenomena (ENSO, ENSO Modoki, Indian Ocean Dipole, and Nino3) on river water streamflow. This scientific contribution shows a dominant influence of climate variability as compared to any other factors responsible for streamflows on longer time scales. 
Author Contributions: Conceptualization, N.S.; data curation, A.P., L.S. and M.M.; formal analysis, N.S., A.P., S.N., and W.D.; funding acquisition, N.S.; T.S.; methodology, N.S., A.P., S.N., and L.S.; supervision, N.S. and T.S.; visualization, A.S., L.S., and R.A.; writing-original draft, A.P., N.S.; and writing-review and editing, N.S.; A.P.; A.S., S.N., M.M., W.D., R.A., T.S. and S.B. All authors have read and agreed to the published version of the manuscript.

Funding: This work has been supported by JSPS Kakenhi Grant-in-Aid id:18F18360.

Acknowledgments: We are thankful to Mahanadi and Eastern Rivers Organization, Mahanadi Bhavan, Bhubaneswar, Odisha for providing the daily streamflow data of four stations located on river Mahanadi. The license software like Arc GIS 10.7 and MS Office Professional Plus 2019 of DPRI, Kyoto University are used to draw figures. Authors thank National Oceanic and Atmospheric Administration (NOAA), National Climate Data Centre for using the data. Streamflow data are available at http://india-wris.nrsc.gov.in/wris.html. At present, Dr Netrananda Sahu is working as JSPS Postdoc Fellow at DPRI, Kyoto University. We are thankful to JSPS (ID No. P18360), Japan.

Conflicts of Interest: The authors declare no conflict of interest.

\section{References}

1. Chiew, F.; Whetton, P.; McMahon, T. Detection of climate changes in recorded runoff volumes in South-east Australian rivers. Int. J. Clim. 1995, 13, 643-653. [CrossRef]

2. Petpongpan, C.; Ekkawatpanit, C.; Kositgittiwong, D. Climate change impact on surface water and groundwater recharge in Northern Thailand. Water 2020, 12, 1029. [CrossRef]

3. Rochdane, S.; Barbara, R.; Messouli, M.; Abdelaziz, B.; Khebiza, M.Y. Climate change impacts on water supply and demand in Rheraya watershed (Morocco), with potential adaptation strategies. Water 2012, 4, 28-44. [CrossRef]

4. Garc01a, N.O.; Vargas, W.M. The temporal climatic variability in the Rio de la Plata basin displayed by the river discharges. Clim Chang. 1998, 38, 359-379. [CrossRef]

5. Genta, J.L.; Perez Iribarren, G.; Mechoso, C.R. A recent increasing trend in the streamflow of rivers in Southeastern South America. J. Clim. 1998, 11, 2858-2862. [CrossRef]

6. Mostafa, M.M. Experimental study of flow characteristics around floodplain single groyne. J. Hydro-Environ. Res. 2018, 22, 1-13. [CrossRef]

7. Hu, L.; Nikolopoulos, E.I.; Marra, F.; Anagnostou, E.N. Sensitivity of flood frequency analysis to data record, statistical model, and parameter estimation methods: An evalution over the contiguous United States. J. Flood Risk Manag. 2019, 13, e12580. [CrossRef]

8. Opere, A.O.; Mkhandi, S.; Willems, P. At site flood frequency analysis for the Nile equatorial basins. Phys. Chem. Earth Parts A/B/C 2006, 31, 919-927. [CrossRef]

9. Baratti, E.; Montanari, A.; Castellarin, A.; Salinas, J.L.; Viglione, A.; Bezzi, A. Estimating the flood frequency distribution at seasonal and annual time scales. Hydrol. Earth Syst. Sci. 2012, 16, 4651-4660. [CrossRef]

10. Ahilan, S.; Amp, A.P.O.S.; Sullivan, J.J.; Bruen, M. Influences on flood frequency distributions in Irish river catchments. Hydrol. Earth Syst. Sci. 2012, 16, 1137-1150. [CrossRef]

11. Duan, W.; He, B.; Nover, D.; Fan, J.; Yang, G.; Chen, W.; Meng, H.; Liu, C. Floods and associated socioeconomic damages in China over the last century. Nat. Hazards 2016, 82, 401-413. [CrossRef]

12. Zou, S.; Jilili, A.; Duan, W.; Maeyer, P.D.; de Voorde, T.V. Human and Natural Impacts on the Water Resources in the Syr Darya River Basin, Central Asia. Sustainability 2019, 11, 3084. [CrossRef]

13. Wang, D.; Hejazi, M. Quantifying the relative contribution of the climate and direct human impacts on mean annual streamflow in the contiguous United States. Water Resour. Res. 2011, 47, W00J12. [CrossRef]

14. Wagner, T.; Themebl, M.; Schuppel, A.; Gobiet, A.; Stigler, H.; Brik, S. Impacts of climate change on streamflow and hydro power generation in the Alpine region. Environ. Earth Sci. 2017, 76, 4. [CrossRef]

15. Marengo, J.A. Inter-decadal variability and trends of rainfall across the Amazon basin. Theor. App. Climatol. 2004, 78, 79-96. [CrossRef]

16. Marengo, J.A.; Borma, L.S.; Rodriguez, D.A.; Pinho, P.; Soares, W.R.; Alves, L.M. Recent extremes of drought and flooding in Amazonia: Vulnerabilities and human Adaptation. Am. J. Clim Chang. 2013, 2, 87-96. [CrossRef]

17. Marengo, J.A.; Espinoza, J.C. Extreme seasonal droughts and floods in Amazonia: Causes, trends and impacts. Int. J. Climatol. 2016, 36, 1033-1050. [CrossRef] 
18. Nepal, S. Impacts of climate change on the hydrological regime of the Koshi river basin in the Himalayan region. J. Hydro. Environ. Res. 2015, 10, 76-89. [CrossRef]

19. Ward, P.J.; Kummu, M.; Lall, U. Flood frequencies and durations and their response to El Nino Southern Oscillation. J. Hydrol. 2016, 539, 358-378. [CrossRef]

20. Agilan, V.; Umamahesh, N.V. Changes in ENSO and IOD Effects on the extreme rainfall of Hyderaba d city, India. In Climate Change Impacts; Singh, V., Yadav, S., Yadava, R., Eds.; Springer: Singapore, 2018; Volume 82.

21. Guangju, Z.; Peng, T.; Xingmin, M.; Juying, J.; Fei, W.; Peng, G. Quantifying the impact of climate variability and human activities on steamflow in te middle reaches of the Yellow River basin, China. J. Hydrol. 2014, 519, 387-398.

22. Mabuku, M.P.; Senzanje, A.; Mudhara, M.; Jewitt, G.P.W.; Mulwafu, W.O. Strategiesfor coping and adapting to flooding and their determinants: A comparative study of cases from Namibia and Zambia. Phys. Chem. Earth Parts A/B/C 2009, 111, 20-34. [CrossRef]

23. Reynolds, R.W.; Smith, T.M.; Liu, C.; Chelton, D.B.; Casey, K.S.; Schlax, M.G. Daily high-resolution blended analysis for sea surface temperature. J. Clim. 2007, 20,5473-5496. [CrossRef]

24. Rice, J.S.; Emanuel, R.E. How are streamflow responses to the El Nino Southern Oscillation affected by watershed characteristics? Water Resour Res. 2017, 53, 4393-4406. [CrossRef]

25. Petra, D.; Schmied, H.M. How is the impact of climate change on river flow regimes related to the impact of mean annual runoff? A global-scale analysis. Environ. Res. Lett. 2012, 7, 014037.

26. Jefferson, A.; Nolin, A.; Lewis, S.; Tague, C. Hydrogeologic controls on streamflow sensitivity to climate variation. Hydrol. Process. 2008, 22, 4371-4385. [CrossRef]

27. Christopher, P.D.M.; Wetherald, R.T.; Dunne, K.A.; Delworth, T.L. Increasing risk of great floods in a changing climate. Nature 2002, 415, 514-517.

28. Maghsood, F.F.; Moradi, H.; Massah, A.R.; Panahi, M.; Hashmei, H. Climate change impact on flood frequency and source area in Northern Iran under CMIP5 Scenarios. Water 2018, 11, 273. [CrossRef]

29. Mohapatra, M.; Mohanty, U.C. Spatio-temporal variability of summer monsoon rainfall over Orissa in relation to low pressure systems. J. Earth Syst. Sci. 2006, 115, 203-218. [CrossRef]

30. Dutta, D.; Asokan, M.S. Analysis of water resources in the Mahanadi river basin, India under projected climate conditions. Hydrol. Process. 2008, 22, 3589-3603.

31. Swain, S. Impact of Climate Variability over Mahanadi River Basin. Int. J. Eng. Res. Technol. 2014, 3, $938-943$.

32. Nharo, T.; Makurira, H.; Gumindoga, W. Mapping floods in the middle Zambezi Basin using earth observation and hydrological modeling techniques. Phys. Chem. Earth Parts A/B/C 2019, 114, 102787. [CrossRef]

33. Zhai, Y.; Wang, C.; Chen, G.; Li, X.; Liu, Y. Field based analysis of runoff generation processes in Humid lowlands of the Taihu Basin, China. Water 2020, 12, 1216. [CrossRef]

34. Bodian, A.; Diop, L.; Panthou, G.; Dacosta, H.; Deme, A.; Dezetter, A.; Diouf, I.; Vischel, T. Recent trend in Hydroclimatic conditions in the Senegal river basin. Water 2020, 12, 436. [CrossRef]

35. Panda, A.; Sahu, N.; Behera, S.K.; Sayama, T.; Sahu, L.; Ram, A.; Singh, R.B.; Yamada, M. Impact of Climate Variability on Crop yield in Kalahandi, Bolangir and Koraput Districts of Odisha, India. Climate 2019, 7, 126. [CrossRef]

36. Sahu, N.; Yamashaki, Y.; Behera, S.; Takara, K.; Yamagata, T. Large impacts of Indo-Pacific climate modes on the extreme Streamflows of Citarum river in Indonesia. J. Glob. Environ. Eng. 2012, 17, 1-8.

37. Sahu, N.; Singh, R.B.; Kumar, P.; Silva, R.V.; Behera, S. La Niña Impacts on Austral Summer Extremely High-Streamflow Events of the Paranaíba River in Brazil. Adv. Meteorol. 2013, 2013, 1-6. [CrossRef]

38. Sahu, N.; Behera, S.; Ratnam, J.V.; Silva, R.V.; Parhi, P.; Duan, W.; Takara, K.; Singh, R.B.; Yamagata, T. El Nino Modoki connection to extremely low streamflow of the Paranaiba river in Brazil. Clim. Dyn. 2014, 42, 1509-1516. [CrossRef]

39. Sahu, N.; Behera, S.K.; Yamashiki, Y.; Takara, K.; Yamagata, T. IOD and ENSO impacts on the extreme streamflows of Citarum river in Indonesia. Clim. Dyn. 2012, 39, 1673-1680. [CrossRef]

40. Mishra, B.K.; Kaoru, T.; Yamashiki, Y.; Tachikawa, Y. Hydrologic simulation-aided regional flood frequency analysis of Nepalese river basins. J. Flood Risk Manag. 2009, 2, 243-253. [CrossRef]

41. Mishra, B.K.; Herath, S. Climate projections downscaling and impact assessment on precipitation over upper Bagmati river basin, Nepal. In Proceedings of the Third International Conference on Addressing Climate Change for Sustainable Development, Kathmandu, Nepal, 12-14 October 2011; pp. 275-281. 
42. Mahanadi Basin Gazzette Report, Central Water Commission, Ministry of Water Resources, Govt.of India. 2014. Available online: http://www.cwc.gov.in/mero/ (accessed on 7 July 2020).

43. Flood Estimation Report for Mahanadi Subzone; Directorate of Hydrology, Hydrology Study organisation: New Delhi, India, 2000.

44. Alexandersson, H. A homogeneity test applied to precipitation data. J. Climatol. 1986, 6, 661-675. [CrossRef]

45. Ashok, K.; Yamagata, T. Climate Change: The El Nino with a Difference. Nature 2009, 461, 481-484. [CrossRef]

46. Cai, W.; Cowan, T. La Nina Modoki impacts Australia autumn rainfall variability. Geophys. Res. Lett. $2009,36$. [CrossRef]

47. Ashok, K.; Behera, S.K.; Rao, S.A.; Weng, H.; Yamagata, T. El Nino Modoki and its possible teleconnection. JGR-Ocean 2007, 112. [CrossRef]

48. Saji, H.; Goswami, B.N.; Vinayachandran, P.; Yamagata, T. A dipole mode in the tropical Indian Ocean. Nature 1999, 401, 360-363. [CrossRef] [PubMed]

49. Panda, D.K.; Kumar, A.; Ghosh, S.; Mohanty, R.K. Streamflow trends in the Mahanadi river basin (India): Linkages to tropical climate variability. J. Hydrol. 2013, 495, 135-149. [CrossRef]

50. Sayama, T.; Tatebe, Y.; Iwami, Y.; Tanaka, S. Hydrologic sensitivity of flood runoff and inundation: 2011 Thailand floods in the Chao Phraya River basin. Nat. Hazards Earth Syst. Sci. 2015, 15, 1617-1630. [CrossRef]

51. Kuntiyawichai, K.; Amporn, W.S.; Wongsasri, S.; Chindaprasirt, P. Anticipating of potential climate and land use impacts on floods: A case study of the lower Nam Phong river basin. Water 2020, 12, 1158. [CrossRef]

52. Jun, T. Combined impact of climate and land use changes on streamflow and water quality in eastern Massachusttes. USA J. Hydrol. 2009, 379, 268-283.

53. Maity, R.; Kumar, D.N. Hydroclimatic influence of large scale circulation on the variability of reservoir inflow. Hydrol. Process. 2009, 23, 934-942. [CrossRef]

54. Maity, R.; Kashid, S.S. Importance analysis of local and global climate inputs for basin-scale streamflow prediction. Water Resour. Res. 2011, 47, 1-17. [CrossRef]

55. Pandey, G.R.; Nguyen, V.-T.-V. Comparative study of regression based methods in regional flood frequency analysis. J. Hydrol. 1999, 225, 92-101. [CrossRef]

56. Coles, S.; Bawa, I.; Trenner, L.; Dorazio, P. An Introduction to Statistical Modeling of Extreme Values; Springer: London, UK, 2001.

57. Kamal, V.; Mukherjee, S.; Singh, P.; Sen, R.; Vishwakarma, C.A.; Sajadi, P.; Asthana, H.; Rena, V. Flood frequency analysis of Ganga river at Haridwar and Garhmukteshwar. Appl. Water Sci. 2017, 7, 1979-1986. [CrossRef]

58. Jefrin, N.; Bolong, N.; Sentian, J.; Abustan, I.; Mohammad, T.A.; Ayog, J.L. Comparison of GEV and Gumble's Distribution for Development of Intensity Duration Frequency Curve for Flood Prone Area in Sabah. Malays. J. Geosci. 2018, 2, 42-44. [CrossRef]

59. Nayak, S.; Takemi, T. Dependence of extreme precipitable water events on temperature. Atmósfera 2019, 32, 159-265. [CrossRef]

60. Panda, A.; Sahu, N. Trend analysis of seasonal rainfall and temperature pattern in Kalahandi, Bolangir and Koraput districts of Odisha, India. Atmos. Sci. Lett. 2019, 20, e932. [CrossRef]

61. Nayak, S. Do extreme precipitation intensities linked to temperature over India follow the Clausius-Clapeyron relationship? Curr. Sci. 2018, 115, 391-392. [CrossRef]

(C) 2020 by the authors. Licensee MDPI, Basel, Switzerland. This article is an open access article distributed under the terms and conditions of the Creative Commons Attribution (CC BY) license (http://creativecommons.org/licenses/by/4.0/). 